\title{
A New Heptamethine Cyanine-Based Near-Infrared Fluorescent Probe for Divalent Copper Ions with High Selectivity
}

\author{
Zhixiang Han ${ }^{1,3^{*}}$, Qingqing Yang ${ }^{1}$, Lihui Liang ${ }^{2 *}$, Xiaobing Zhang ${ }^{3}$ \\ ${ }^{1}$ School of the Environment and Safety Engineering, Jiangsu University, Zhenjiang, China \\ ${ }^{2}$ Hunan Provincial People's Hospital, Changsha, China \\ ${ }^{3}$ State Key Laboratory of Chemo/Biosensing and Chemometrics, College of Chemistry \& Chemical Engineering, \\ Hunan University, Changsha, China \\ Email: ${ }^{*}$ zhixianghan69@126.com, ${ }^{*} 416284649 @ q q . c o m$
}

Received November 4, 2013; revised December 5, 2013; accepted December 16, 2013

Copyright (C) 2013 Zhixiang Han et al. This is an open access article distributed under the Creative Commons Attribution License, which permits unrestricted use, distribution, and reproduction in any medium, provided the original work is properly cited. In accordance of the Creative Commons Attribution License all Copyrights (C) 2013 are reserved for SCIRP and the owner of the intellectual property Zhixiang Han et al. All Copyright (C) 2013 are guarded by law and by SCIRP as a guardian.

\begin{abstract}
A new near-infrared fluorophore 2-(2-Aminoethyl) pyridine-tricarbocyanine (1) was rationally designed and synthesized as a fluorescent probe for detection of $\mathrm{Cu}^{2+}$ with high selectivity. The response of Probe $\mathbf{1}$ is based on the fluorescence quenching upon binding to $\mathrm{Cu}^{2+}$. The sensing performance of the proposed $\mathrm{Cu}^{2+}$-sensitive Probe 1 was then investigated. The probe can be applied to the quantification detection of $\mathrm{Cu}^{2+}$ with a linear concentration range covering from $4.8 \times 10^{-7}$ to $1.6 \times 10^{-4} \mathrm{~mol} / \mathrm{L}$ and a detection limit of $9.3 \times 10^{-8} \mathrm{~mol} / \mathrm{L}$. The experimental results showed that the response of 1 to $\mathrm{Cu}^{2+}$ was independent of $\mathrm{pH}$ in medium condition $(\mathrm{pH} 6.0-8.0$ ), and exhibited excellent selectivity towards $\mathrm{Cu}^{2+}$ over other common metal cations.
\end{abstract}

Keywords: Near-Infrared Dye; Fluorescent Probe; $\mathrm{Cu}^{2+}$ Ions

\section{Introduction}

The design and synthesis of fluorescent probes for selective and sensitive detection of metal ions have attracted wide-spread interests of chemists, biologists, clinical biochemists and environmentalists in recent years [1]. Copper is an essential trace element in both plants and animals, including humans. Among the essential heavy metals, the abundance of copper ranks the third in human body. It participates in many biological processes, such as haemoglobin synthesis (in utilization of $\mathrm{Fe}$ and regeneration of $\mathrm{Hb}$ ), development of connective tissue, normal functions of the central nervous system, and oxidative phosphorylation [2-4]. Nevertheless, copper of high concentration is highly toxic to some organisms such as many bacteria and viruses [5]. Owing to its toxicity for bacteria, elevated concentrations of copper would ham- per the self-purification capability of the sea or rivers, and destroy the biological reprocessing systems

*Corresponding author. in water. Copper is also found to be harmful to human at high concentration and has been suspected to cause the damage of infant liver in recent years. Accordingly, searching for efficient and reproducible analytical methods for the copper assay is of great importance for environment and human health.

Many analytical methods for detection of copper, including atomic absorption spectrometry (AAS) [6], inductively coupled plasma-mass spectroscopy (ICP-MS) [7], inductively coupled plasma-atomic emission spectrometry (ICP-OES) [8], spectrophotometry [9], voltammetry [10] and fluorescence spectroscopy [11], have been developed so far. Among these methods, fluorescence spectroscopy offers significant advantages due to its nondestructive character, high sensitivity and specificity, and the availability of a wide range of indicative dyes. Several fluorophores have been used to design fluorescent probes for divalent copper ions including calcein [12], rhodamine [13], naphthalimide [14,15], pyrene [16,17], tris(2,2'-bipyridine)-ruthenium(II) [18], ben- 
zoxazole [19], porphyrin [20,21], spiropyran [22,23], BODIPY [24], and so on. Unfortunately, limitations of the currently available probes for $\mathrm{Cu}^{2+}$ include low sensitivity, and/or excitation profiles in the ultraviolet or visible region, which can damage living samples and cause interfering autofluorescence from native cells.

The light in the near-infrared region (NIR) around $650-900 \mathrm{~nm}$ can penetrate more deeply into tissues, which is of importance to study on living organism imaging. Moreover, it has a further advantage that autofluorescence is not observed upon NIR excitation. Heptamethine cyanine dyes [25], one of the important kinds of NIR dyes, has been widely used in various fields, and been employed as fluorescent labels in the studies of fluorescence imaging with biological mechanisms. And a few probes based on heptamethine cyanine dyes have been employed to detect metal ions or small molecules [26]. However, to the best of our knowledge, only few NIR fluorescent probes based on cyanine dyes have been reported for divalent copper ion assay detection [27]. Searching for new NIR probe for copper detection with high selectivity is still an active field as well as a challenge for the analytical chemistry research.

Herein, we report the synthesis and properties of a novel NIR fluorescent probe 2-(2-Aminoethyl) pyridinetricarbocyanine (1) for the detection of $\mathrm{Cu}^{2+}$ with good selectivity and high sensitivity. Tricarbocyanine and 2-(2-aminoethyl) pyridine were selected as the reporter and cheleator, respectively. The probe exhibited stable response towards $\mathrm{Cu}^{2+}$ over the concentration range from $4.8 \times 10^{-7}$ to $1.6 \times 10^{-4} \mathrm{~mol} / \mathrm{L}$ with a working $\mathrm{pH}$ range from $\mathrm{pH} 6.0$ to 8.0 .

\section{Experimental}

\subsection{Reagents}

Before being used, N, N'-dimethylformamide (DMF) was subjected to simple distillation from $\mathrm{K}_{2} \mathrm{CO}_{3}$. IR-780 iodide was purchased from Sigma-Aldrich. 2-(2-Aminoethyl) pyridine was purchased from Alfa Aesar. All other chemicals were of analytical reagent grade, purchased from Shanghai chemical Reagent Corporation (Shanghai, China), and used without further purification. Twice distilled water was used throughout all experiments. Thin layer chromatography (TLC) was carried out using silica gel 60 F254, and column chromatography was conducted over silica gel (100 - 200 mesh), both of which were obtained from the Qingdao Ocean Chemicals (Qingdao, China).

\subsection{Synthesis of Compound 1}

Synthetic route for Compound 1 was depicted in Scheme 1. Briefly, IR-780 iodide $(11.3 \mathrm{mg}, 0.0167 \mathrm{mmol})$ and 2-(2-Amino-ethyl) pyridine $(20.4 \mathrm{mg}, 0.167 \mathrm{mmol})$ were

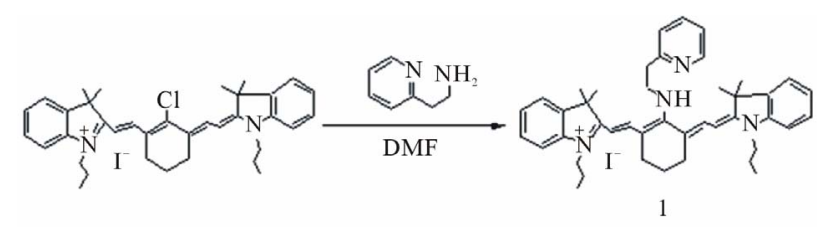

Scheme 1. Synthetic pathway of Compound 1.

dissolved in anhydrous DMF $(3 \mathrm{~mL})$ in a $25 \mathrm{~mL}$ round bottom flask. The mixture was stirred at $80^{\circ} \mathrm{C}$ for $4 \mathrm{~h}$ under an argon atmosphere. The solvent was removed under reduced pressure, then purified on silica gel chromatography eluted with $\mathrm{CH}_{2} \mathrm{Cl}_{2}$ /ethanol $(100: 1, \mathrm{~V} / \mathrm{V})$ to afford the desired product as a blue solid $(7.1 \mathrm{mg}$, yield 56\%). ${ }^{1} \mathrm{H}$ NMR $\left(400 \mathrm{MHz}, \mathrm{CDCl}_{3}\right): \delta 0.93(\mathrm{t}, 6 \mathrm{H}, \mathrm{J}=7.4$ $\mathrm{Hz}), 1.55(\mathrm{~s}, 12 \mathrm{H}), 1.63-1.73(\mathrm{~m}, 6 \mathrm{H}), 2.45(\mathrm{t}, 4 \mathrm{H}, \mathrm{J}=6.0$ $\mathrm{Hz}), 3.21(\mathrm{t}, 2 \mathrm{H}, \mathrm{J}=6.4 \mathrm{~Hz}), 3.92(\mathrm{t}, 4 \mathrm{H}, \mathrm{J}=6.8 \mathrm{~Hz})$, 4.14(d, 2H, J =6.4 Hz), $5.76(\mathrm{~m}, 2 \mathrm{H}), 7.05(\mathrm{t}, 2 \mathrm{H}, \mathrm{J}=6.8$ $\mathrm{Hz}), 7.15(\mathrm{~d}, 2 \mathrm{H}, \mathrm{J}=8.0 \mathrm{~Hz}), 7.27-7.33(\mathrm{~m}, 4 \mathrm{H}), 7.43(\mathrm{~m}$, $2 \mathrm{H}), 7.60(\mathrm{~d}, 2 \mathrm{H}, \mathrm{J}=12.8 \mathrm{~Hz}), 7.75(\mathrm{~m}, 1 \mathrm{H}), 8.50(\mathrm{~d}, 1 \mathrm{H}, \mathrm{J}$ $=5.2 \mathrm{~Hz}), 8.68(\mathrm{br}, 1 \mathrm{H})$. ESI-MS: $\left[\mathrm{M}-\mathrm{I}^{-}\right]=625.3$, calculated: $[\mathrm{M}]^{+}=625.9$.

\subsection{Apparatus}

${ }^{1} \mathrm{H}$ NMR spectra were recorded on a INOVE-400 (Varian) spectrometer operating at $400 \mathrm{MHz}$. All chemical shifts are reported in the standard $\delta$ notation of parts per million. LC-MS analyses were performed using an Agilent 1100 HPLC/MSD spectrometer; UV-Vis absorption spectra were recorded with a Shimadzu MultiSpec-1501 spectrophotometer. All fluorescence measurements were carried out on a HITACHI F4500 (Japan) with excitation slit set at $10.0 \mathrm{~nm}$ and emission at $20.0 \mathrm{~nm}$. The $\mathrm{pH}$ measurements were carried out on Mettler-Toledo Delta $320 \mathrm{pH}$ meter (Shanghai, China).

\subsection{Measurement Procedures}

4-(2-Hydroxyethyl) piperazine-1-ethanesulfonic acid (HEPES) buffer $\left\{0.1 \mathrm{~mol} / \mathrm{L}, \mathrm{pH}=7.4, \mathrm{I}=0.1\left(\mathrm{NaNO}_{3}\right)\right\}$ were prepared by dissolving appropriate HEPES and $\mathrm{NaNO}_{3}$ in water, adjusting to $\mathrm{pH}=7.4$ by $1.0 \mathrm{~mol} / \mathrm{L}$ $\mathrm{NaOH}$ with the volume to $1000 \mathrm{ml}$ in a volumetric flask.

A $2.0 \times 10^{-5} \mathrm{~mol} / \mathrm{L}$ stock solution of 1 was prepared by dissolving 1 in $\mathrm{CH}_{3} \mathrm{CN}$. A stock standard solution of $\mathrm{Cu}^{2+}(0.01 \mathrm{~mol} / \mathrm{L})$ was prepared by dissolving an appropriate amount copper in water and adjusting the volume to $100 \mathrm{ml}$, then further diluted to $1 \times 10^{-3}-1 \times 10^{-7}$ $\mathrm{mol} / \mathrm{L}$ stepwise. The buffered solutions of wide $\mathrm{pH}$ range were obtained by adjustment of $0.1 \mathrm{~mol} / \mathrm{L}$ HEPES solution with $\mathrm{HCl}$ or $\mathrm{NaOH}$ solution. The complex solution of $\mathrm{Cu}^{2+} / 1$ was prepared by adding $5.0 \mathrm{~mL}$ the stock solution of 1 and $1.0 \mathrm{~mL}$ mentioned above solution of $\mathrm{Cu}^{2+}$ in a $10 \mathrm{~mL}$ volumetric flask. Then the mixture was diluted to $10 \mathrm{~mL}$ with $\mathrm{pH} 7.4$ HEPES buffer solution. In the ob- 
tained solution, the concentrations were $1 \times 10^{-5} \mathrm{~mol} / \mathrm{L}$ of 1 and $1 \times 10^{-3}-1 \times 10^{-8} \mathrm{~mol} / \mathrm{L}$ of $\mathrm{Cu}^{2+}$. Blank solution of $\mathbf{1}$ was prepared under the same conditions without $\mathrm{Cu}^{2+}$. All the solution above were protected from light and kept at $4^{\circ} \mathrm{C}$ for further use.

\section{Results and Discussion}

\subsection{Spectral Characteristics}

Figure 1 showed the fluorescence spectra of 1 in HEPES buffer solutions with different concentrations of $\mathrm{Cu}^{2+}$, which recorded at excitation wavelength of $640 \mathrm{~nm}$ and emission wavelength of $670-800 \mathrm{~nm}$. The spectrum of free 1 exhibited very strong fluorescence emission in a buffer solution. Addition of $\mathrm{Cu}^{2+}$ to a solution of $\mathbf{1}$, fluorescence signal exhibited a remarkable quenching. The fluorescence intensity of $\mathbf{1}$ was gradually decreased with increasing $\mathrm{Cu}^{2+}$ concentration. These results provided a proof for the formation of an inclusion complex of $\mathbf{1}$ with $\mathrm{Cu}^{2+}$, which constituted the basis for the determination of $\mathrm{Cu}^{2+}$ concentration with 1 . It is worthy to note that the fluorescence intensity of Probe $\mathbf{1}$ can be recovered upon addition of the coordinating reagents ethylenediaminetetraacetic acid (EDTA).

In order to better understand the variation of fluorescence intensity with the concentrations of $\mathrm{Cu}^{2+}$, the absorption spectra of $\mathbf{1}$ in the absence and presence of $\mathrm{Cu}^{2+}$ were recorded (Figure 2). In the absorption spectrum of 1, the results showed a strong absorption band at $643 \mathrm{~nm}$ in the absence of $\mathrm{Cu}^{2+}$, while the addition of $\mathrm{Cu}^{2+}$ ions decreased with no obvious shift in absorbance at $643 \mathrm{~nm}$. From the fluorescence spectra and UV-is spectra, it is indicated that the fluorescence changes of $\mathbf{1}$ were more likely to be caused by the change of quantum yield rather than spectral shifts. Similar results were reported by Tang et al. [28].

In addition, Probe 1 works well and no detectable change in the linear range, detection limit or other analytical performance is found after it has been stored for several weeks in the dark at $4^{\circ} \mathrm{C}$, which implies that the NIR fluorescent probe used is stable.

\subsection{Principle of Operation}

The complexation equilibrium of $\mathbf{1}$ (A) with $\mathrm{Cu}^{2+}$ (B) with an association constant $\mathrm{K}$ can be expressed by the following equation:

$$
m B+n A \stackrel{K}{\longleftrightarrow} A_{n} B_{m}
$$

where $\mathrm{Cu}^{2+}(\mathrm{B})$ and $\mathbf{1}(\mathrm{A})$ is established by formation of a complex with a complexing ratio of $\mathrm{m}: \mathrm{n}$. According to the modified Stern-Volmer equation [29], the relationships for the changes of fluorescence intensities, the concentration of $\mathrm{Cu}^{2+}[\mathrm{B}]$ in solution and the concentration of $\mathbf{1}[\mathrm{A}]$ in solution can be expressed as follows:

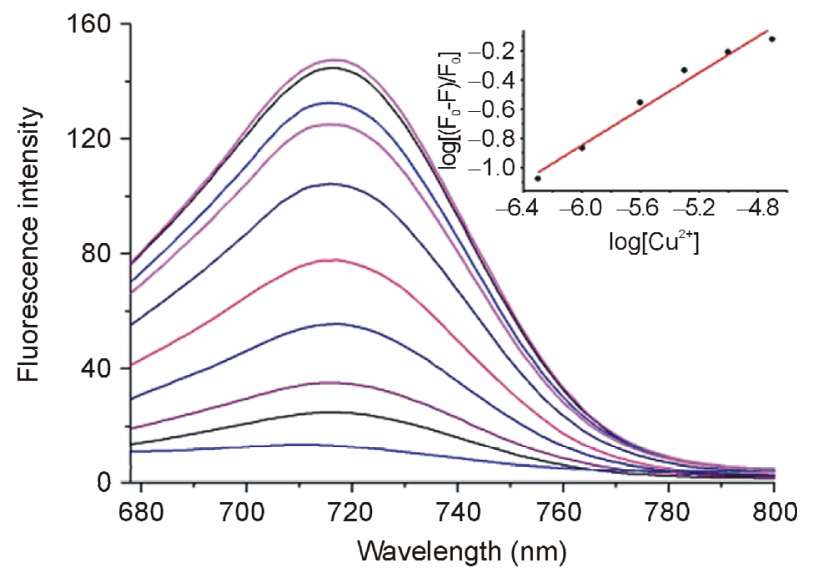

Figure 1. Fluorescence emission spectrum of $1(10 \mu \mathrm{mol} / \mathrm{L})$ with different concentration of $\mathrm{Cu}^{2+}$ (From top to bottom: 0 , 0.5, 1.0, 2.5, 5.0, 10, 20, 50, 100, $200 \mu \mathrm{mol} / \mathrm{L})$ in $\mathrm{CH}_{3} \mathrm{CN} / \mathrm{H}_{2} \mathrm{O}$ $(1: 1, \mathrm{v} / \mathrm{v})$ solution. Inset shows the linear responses with divalent copper ions concentrations.

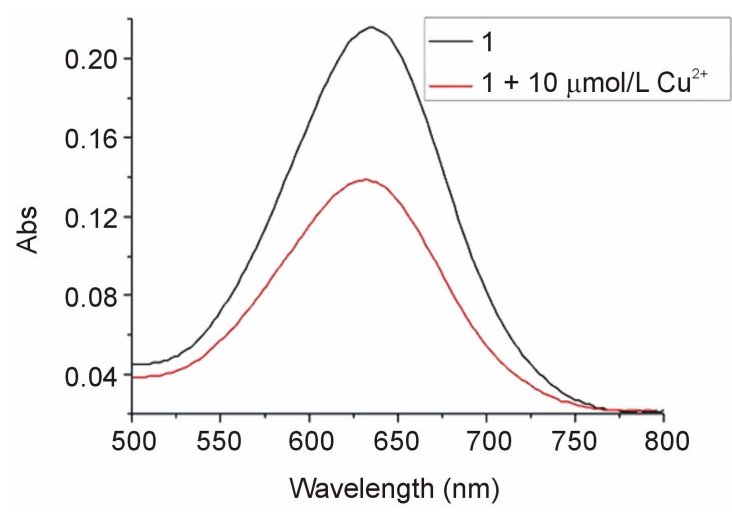

Figure 2. Chages in the UV-vis spectra of $1(10 \mu \mathrm{mol} / \mathrm{L})$ (black line) upon the addition of $\mathrm{Cu}^{2+}(10 \mu \mathrm{mol} / \mathrm{L})$ (red line).

$$
\frac{F_{0}-F}{F}=K_{q}[A]^{n-1}[B]^{m}
$$

Assuming $\Delta F=F_{0}-F$, one can obtain:

$$
\log \left(\frac{\Delta F}{F}\right)=\log K_{q}+(n-1) \log [A]+m \log [B]
$$

Here $F_{0}$ and $F$ denote the fluorescence intensities of 1 in the absence and presence of $\mathrm{Cu}^{2+}$, respectively. $K_{q}$ is fluorescence quenching constant. The calibration curve was constructed by recording the fluorescence intensity values of $\mathbf{1}$ in the presence of different $\mathrm{Cu}^{2+}$ concentration. In the range between $1.0 \times 10^{-7}$ and $5.0 \times 10^{-5}$ $\mathrm{mol} / \mathrm{L} \mathrm{Cu}^{2+}$, the fluorescence intensity is linearly dependent on the $\mathrm{Cu}^{2+}$ concentration. The dependency can be described by the following equation:

$$
\log \left(\frac{\Delta F}{F}\right)=0.9343 \log \left[\mathrm{Cu}^{2+}\right]+4.80
$$

It is obvious from Equation (4) that $\mathrm{m}$ is the slope of 
$\log (\Delta \mathrm{F} / \mathrm{F})$ versus $\log \left[\mathrm{Cu}^{2+}\right]$, which was calculated to be 1 approximately. Quenching constant $(\mathrm{Kq})$ is $6.3 \times 10^{4}$. The relative fluorescence intensity $\alpha$ is defined as the ratio of free $\mathrm{A}[\mathrm{A}]_{\mathrm{f}}$, to the total amount of $\mathrm{A}[\mathrm{A}]_{\mathrm{t}}$, in the solution. It can be experimentally determined by measuring the fluorescence intensity of $\mathbf{1}$ in the solution:

$$
\frac{[A]_{f}}{[A]_{t}}=\frac{F-F_{t}}{F_{b}-F_{t}}
$$

Here $F_{b}$ is the fluorescence intensity of $\mathbf{1}$ in the blank buffer solution and $F_{t}$ represents the fluorescence intensity of $\mathbf{1}$ in the solution when $\mathbf{1}$ is completely complexed with $\mathrm{Cu}^{2+} . F$ is the fluorescence intensity of $\mathbf{1}$ actually measured when in contact with $\mathrm{Cu}^{2+}$ solutions of a given concentration. The relationship between the $\boldsymbol{\alpha}$ and $\mathrm{Cu}^{2+}$ concentration $[\mathrm{B}]$ can be represented as:

$$
\frac{\alpha^{n}}{1-\alpha}=\frac{1}{n K[A]_{t}^{n-1}[B]^{m}}
$$

The response of $\mathbf{1}$ for different concentrations of $\mathrm{Cu}^{2+}$ was shown in Figure 3. Three curves are calculated using Equation (6) with different $\mathrm{K}$ and ratios of $\mathrm{Cu}^{2+}$ and $\mathbf{1}$. It can be seen that the best curve was 1:1 complex ratio and an appropriate $\mathrm{K}$ of $1.09 \times 10^{5}$ fits form the experimental data. The curve can serve as the calibration curve for the detection of $\mathrm{Cu}^{2+}$ concentration. A practically usable range for quantitative determination covered from $4.8 \times 10^{-7}$ to $1.6 \times 10^{-4} \mathrm{~mol} / \mathrm{L}(0.05 \leq \alpha \leq 0.95)$ [29]. The detection limit was $9.3 \times 10^{-8} \mathrm{~mol} / \mathrm{L}$ (defined as three times standard deviation of blank solution).

\subsection{Effect or $\mathbf{p H}$}

The effects of $\mathrm{pH}$ on the fluorescence intensity of $\mathbf{1}$ in the presence of $\mathrm{Cu}^{2+}$ were carried out at a $\mathrm{pH}$ range from 5.0 to 9.0 with fixed the $\mathrm{Cu}^{2+}$ concentration at $5 \mu \mathrm{mol} / \mathrm{L}$ (Figure 4). In lower $\mathrm{pH}$ value, the fluorescence intensity of 1 decreased with decreasing $\mathrm{pH}$ value, which might be caused by the protonation of Compound 1 without binding with the metal ion. On the other hand, too high $\mathrm{pH}$ would lead to form the precipitation of $\mathrm{Cu}(\mathrm{OH})_{2}$, and reduce its complexation with 1 . In a wide range of $\mathrm{pH}$ from 6.0 to 8.0 , acidity did not affect the determination of $\mathrm{Cu}^{2+}$ with Compound 1 . In other words, the response behavior of Compound $\mathbf{1}$ is independent of $\mathrm{pH}$ in medium condition, which is convenient for practical applications of the proposed probe in determination of $\mathrm{Cu}^{2+}$.

\subsection{Selectivity}

Under the same conditions, the ability of 1 to recognize $\mathrm{Cu}^{2+}$ was further investigated by mixture $100 \mu \mathrm{mol} / \mathrm{L}$ $\mathrm{Cu}^{2+}$ with the other background anions and metal ions. The experiments were carried out by recording the changes of the fluorescence intensity before and after adding the interferants into the $\mathrm{pH} 7.4$ HEPES buffer solution. As shown from Figure 5, one can see that the proposed probe exhibited a relatively high selectivity for $\mathrm{Cu}^{2+}$ ions over a large number of mono-, bi-, and trivalent cations. Fortunately, normal interferents like $\mathrm{Hg}^{2+}$ do not interfere, which is better than that of the probe reported in literatures.

\subsection{Preliminary Analytical Application}

The proposed probe was applied to the determination of copper ions in water samples of Xiang River. The river water samples were simply filtrated and showed that no $\mathrm{Cu}^{2+}$ was present in them. All the water samples were spiked with standard $\mathrm{Cu}^{2+}$ solutions at different concentration levels, and then analyzed their concentrations with proposed Probe 1. Results are shown in Table 1. One can see that the recovery study of spiked $\mathrm{Cu}^{2+}$

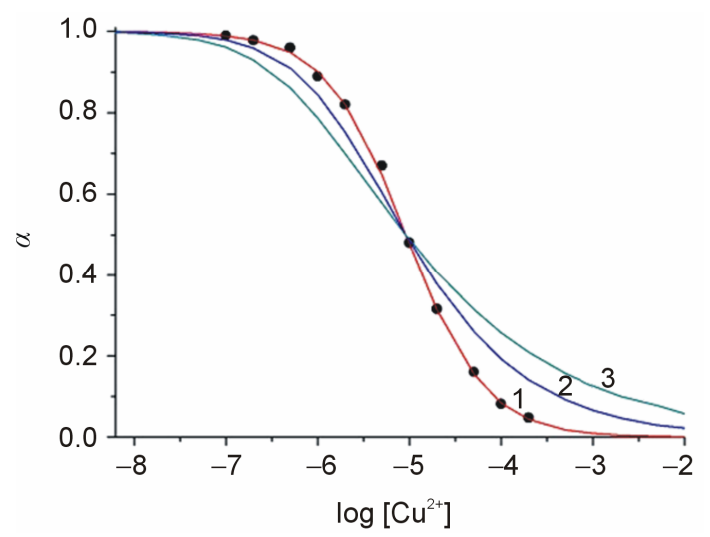

Figure 3. Relative fluorescence intensity $\alpha$ of 1 as a function of $\log \left[\mathrm{Cu}^{2+}\right]$ in $\mathrm{CH}_{3} \mathrm{CN} / \mathrm{H}_{2} \mathrm{O}(1: 1, \mathrm{v} / \mathrm{v})$ solution. The curves fitting the experimental data were calculated from Equation (6). (1) $\mathrm{m}: \mathrm{n}=1: 1, \mathrm{~K}=1.09 \times 10^{5}$; (2) $\mathrm{m}: \mathrm{n}=1: 2, \mathrm{~K}=1.09 \times$ $10^{10}$; (3) $\mathrm{m}: \mathrm{n}=1: 3, \mathrm{~K}=1.46 \times 10^{15}$. (•) data points experimentally obtained.

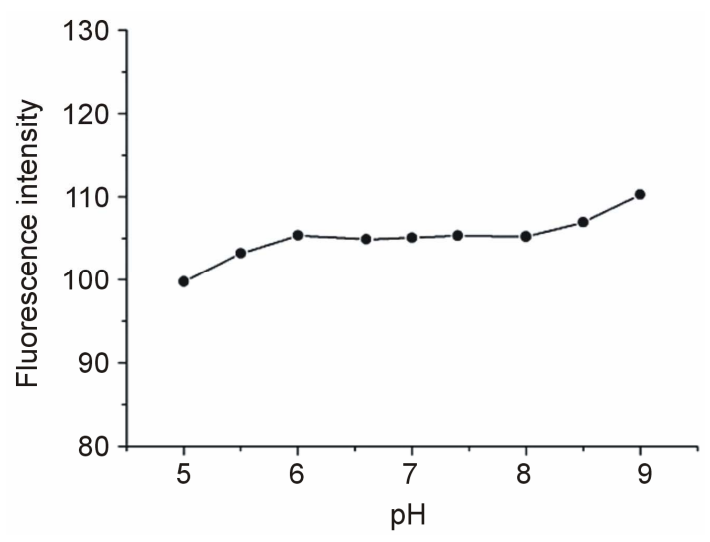

Figure 4. Effect of $\mathrm{pH}$ on the emission of $1(10 \mu \mathrm{mol} / \mathrm{L})$ with $5 \mu \mathrm{mol} / \mathrm{L} \mathrm{Cu^{2+ }}$ at $715 \mathrm{~nm}$ in $\mathrm{CH}_{3} \mathrm{CN} / \mathrm{H}_{2} \mathrm{O}(1: 1, \mathrm{v} / \mathrm{v})$ solution. Excitation was provided at $640 \mathrm{~nm}$. 


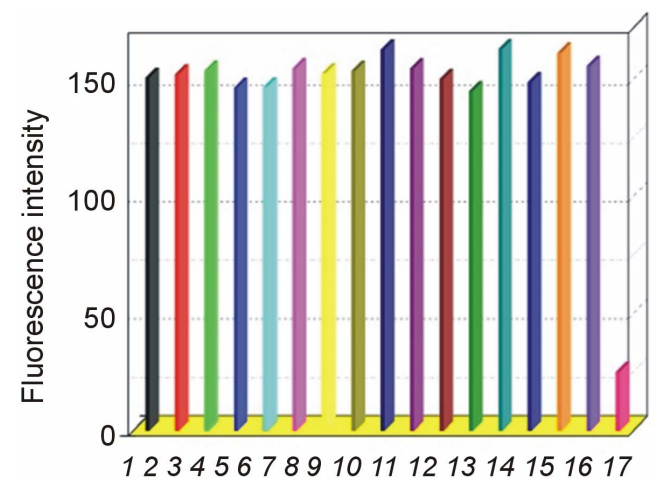

Figure 5. Emission change of 1 at $715 \mathrm{~nm}$ upon addition of each cation in $\mathrm{CH}_{3} \mathrm{CN} / \mathrm{H}_{2} \mathrm{O}(1: 1, \mathrm{v} / \mathrm{v})$ solution at $\mathrm{pH} 7.40$ $\left\{0.1 \mathrm{~mol} / \mathrm{L}\right.$ HEPES, I $\left.=0.1\left(\mathrm{NaNO}_{3}\right)\right\}: 1$, none; $2, \mathrm{Zn}^{2+} ; 3$, $\mathrm{Cd}^{2+} ; 4, \mathrm{Mn}^{2+} ; 5, \mathrm{Ca}^{2+} ; 6, \mathrm{Mg}^{2+} ; 7, \mathrm{~K}^{+} ; 8, \mathrm{Na}^{+} ; 9, \mathrm{Li}^{+} ; 10$, $\mathrm{Al}^{3+} ; 11, \mathrm{Co}^{2+} ; 12, \mathrm{Ni}^{2+} ; 13, \mathrm{~Pb}^{2+} ; 14, \mathrm{Hg}^{2+} ; 15, \mathrm{Fe}^{3+} ; 16, \mathrm{Ag}^{+}$ 17, $\mathrm{Cu}^{2+}$. With the exception of $\mathrm{Cu}^{2+}, \mathrm{Hg}^{2+}$ and $\mathrm{Al}^{3+}$ where $10^{-4} \mathrm{~mol} / \mathrm{L}$ of cation were added, each solution contained $10^{-3} \mathrm{~mol} / \mathrm{L}$ of interest. The concentration of 1 was 10 $\mu \mathrm{mol} / \mathrm{L}$ and excitation was provided at $640 \mathrm{~nm}$.

Table 1. Recovery study of spiked determination of copper in Xiang River water with proposed Probe 1.

\begin{tabular}{cccc}
\hline Sample & $\begin{array}{c}\mathrm{Cu}^{2+} \text { spiked } \\
(\mathrm{mol} / \mathrm{L})\end{array}$ & $\begin{array}{c}\mathrm{Cu}^{2+} \text { recovered } \\
(\mathrm{mol} / \mathrm{L})\end{array}$ & Recovery $(\%)$ \\
\hline 1 & 0 & 0 & - \\
2 & $1.0 \times 10^{-5}$ & $\left(1.02^{\mathrm{a}} \pm 0.03^{\mathrm{b}}\right) \times 10^{-5}$ & 102.0 \\
3 & $5.0 \times 10^{-6}$ & $\left(4.93^{\mathrm{a}} \pm 0.04^{\mathrm{b}}\right) \times 10^{-6}$ & 98.6 \\
\hline
\end{tabular}

${ }^{\mathrm{a}}$ Average were calculated with $\mathrm{n}=3$, ${ }^{\mathrm{b}}$ Standard deviations.

determined by the 1-based probe showed satisfactory results. The present probe is useful for the determination of $\mathrm{Cu}^{2+}$ in real samples.

\section{Conclusion}

In summary, a new near-infrared fluorescent probe was designed and synthesized for the detection of $\mathrm{Cu}^{2+}$ based on quenching the fluorescence of tricarbocyanine chromophore with 1- $\mathrm{Cu}^{2+}$ complexation. Compared to reported fluorescent probes, 1-based probe showed high selectivity and large stokes shift over existing reagents and methods for the fluorescence determination of $\mathrm{Cu}^{2+}$ in neutral medium. And the proposed method can be used for the determination of $\mathrm{Cu}^{2+}$ in real samples.

\section{Acknowledgements}

This work was supported by the National Natural Science Foundation of China (Grant 20505008, 21105038), "973" National Key Basic Research Program of China (2007CB310500), Ministry of Education of China (NCET-07-0272), and Hunan Natural Science Foundation (06JJ4010, 07JJ3025).

\section{REFERENCES}

[1] A. P. de Silva, H. Q. Gunaratne, T. Gunnlaugsson, A. J. Huxley, C. P. McCoy, J. T. Rademacher and T. E. Rice, "Signaling Recognition Events with Fluorescent Sensors and Switches," Chemical Reviews, Vol. 97, No. 5, 1997, pp. 1515-1566. http://dx.doi.org/10.1021/cr960386p

[2] E. Vuori, A. Huunan-Seppälä and J. O. Kilpiö, "Biologically Active Metals in Human Tissues. I. The Effect of Age and Sex on the Concentration of Copper in Aorta, Heart, Kidney, Liver, Lung, Pancreas and Skeletal Muscle," Scandinavian Journal of Work, Environment \& Health, Vol. 4, No. 2, 1978, pp. 167-175. http://dx.doi.org/10.5271/sjweh.2712

[3] D. Radisky and J. Kaplan, "Regulation of Transition Metal Transport across the Yeast Plasma Membrane," The Journal of Biological Chemistry, Vol. 274, 1999, pp. 4481-4484. http://dx.doi.org/10.1074/jbc.274.8.4481

[4] B. M. Rode and Y. Suwannachot, "The Possible Role of $\mathrm{Cu}(\mathrm{II})$ for the Origin of Life," Coordination Chemistry Reviews, Vol. 190-192, 1999, pp. 1085-1099. http://dx.doi.org/10.1016/S0010-8545(99)00159-9

[5] C. Barranguet, F. P. van den Ende, M. Rutgers, A. M. Breure, M. Greijdanus, J. J. Sinke and W. Admiraal, "Copper-Induced Modifications of the Trophic Relations in Riverine Algal-Bacterial Biofilms," Environmental Toxicology and Chemistry, Vol. 22, No. 6, 2003, pp. 13401349. http://dx.doi.org/10.1002/etc.5620220622

[6] N. Pourreza and R. Hoveizavi, "Simultaneous Preconcentration of $\mathrm{Cu}, \mathrm{Fe}$ and $\mathrm{Pb}$ as Methylthymol Blue Complexes on Naphthalene Adsorbent and Flame Atomic Absorption Determination," Analytica Chimica Acta, Vol. 549, No. 1-2, 2005, pp. 124-128. http://dx.doi.org/10.1016/j.aca.2005.06.037

[7] J. S. Becker, M. V. Zoriy, C. Pickhardt, N. Palomero-Gallagher and K. Zilles, "Imaging of Copper, Zinc, and Other Elements in Thin Section of Human Brain Samples (Hippocampus) by Laser Ablation Inductively Coupled Plasma Mass Spectrometry," Analytical Chemistry, Vol. 77, No. 10, 2005, pp. 3208-3216. http://dx.doi.org/10.1021/ac040184q

[8] Z. H. Li, L. Zhang, Z. P. Zang, X. J. Chang and X. J. Zou, "Attapulgite Modified with 2-Hydroxy-1-Naphthaldehyde as Selective Solid-Phase Extractant for Determination of Copper(II) in Environmental Samples by ICP-OES," Microchim Acta, Vol. 171, No. 1-2, 2010, pp. 161-168. http://dx.doi.org/10.1007/s00604-010-0407-0

[9] J. J. Pinto, C. Moreno and M. García-Vargas, "A Very Sensitive Flow System for the Direct Determination of Copper in Natural Waters Based on Spectrophotometric Detection," Talanta, Vol. 64, No. 2, 2004, pp. 562-565. http://dx.doi.org/10.1016/j.talanta.2004.03.009

[10] V. Beni, V. Ogurtsov, N. Bakunin, D. W. Arrigan and M. Hill, "Development of A Portable Electroanalytical System for the Stripping Voltammetry of Metals: Determination of Copper in Acetic Acid Soil Extracts," Analytica Chimica Acta, Vol. 552, No. 1-2, 2005, pp. 190-200. http://dx.doi.org/10.1016/j.aca.2005.07.058

[11] Y. Zheng, X. Cao, J. Orbulescu, V. Konka, F. M. Andre- 
opoulos, A. M. Pham and R. M. Leblanc, "Peptidyl Fluorescent Chemosensors for the Detection of Divalent Copper," Analytical Chemistry, Vol. 75, No.7, 2003, pp. 1706-1712. http://dx.doi.org/10.1021/ac026285a

[12] L. A. Saari and W. R. Seitz, "Immobilized Calcein for Metal Ion Preconcentration," Analytical Chemistry, Vol. 56, No. 4, 1984, pp. 810-813. http://dx.doi.org/10.1021/ac00268a051

[13] X. Q. Chen, T. Pradhan, F. Wang, J. S. Kim and J. Yoon, "Fluorescent Chemosensors Based on Spiroring-Opening of Xanthenes and Related Derivatives," Chemical Reviews, Vol. 112, No. 3, 2012, pp. 1910-1956. http://dx.doi.org/10.1021/cr200201z

[14] X. H. Qian, Y. Xiao, Y. F. Xu, X. F. Guo, J. H. Qian and W. P. Zhu, " 'Alive' Dyes as Fluorescent Sensors: Fluorophore, Mechanism, Receptor and Imagesin Living Cells," Chemical Communications, Vol. 46, 2010, pp. 6418-6436. http://dx.doi.org/10.1039/c0cc00686f

[15] X. H. Zhao, Q. J. Ma, X. B. Zhang, B. Huang, Q. Jiang, J. Zhang, G. L. Shen and R. Q. Yu, "A Highly Selective Fluorescent Sensor for $\mathrm{Cu}^{2+}$ Based on a Covalently Immobilized Naphthalimide Derivative," Analytical Science, Vol. 26, No. 5, 2010, pp. 585-590. http://dx.doi.org/10.2116/analsci.26.585

[16] R. Martínez, F. Zapata, A. Caballero, A. Espinosa , A. Tarraga and P. Molina, "2-Aza-1,3-butadiene Derivatives Featuring an Anthracene or Pyrene Unit: Highly Selective Colorimetric and Fluorescent Signaling of $\mathrm{Cu}^{2+} \mathrm{Ca}-$ tion," Organic Letters, Vol. 8, No. 15, 2006, pp. 32353238. http://dx.doi.org/10.1021/ol0610791

[17] H. J. Kim, J. Hong, A. Hong, S. Ham, J. H. Lee and J. S. Kim, " $\mathrm{Cu}^{2+}$-Induced Intermolecular Static Excimer Formation of Pyrenealkylamine," Organic. Letters, Vol. 10, No. 10, 2008, pp. 1963-1966. http://dx.doi.org/10.1021/o1800475d

[18] C. L. He, F. L. Ren, X. B. Zhang, Y. Y. Dong and Y. Zhao, "A Fluorescent Chemosensor for Copper(II) Based on a Carboxylic Acid-functionalized Tris(2,2'-bipyridine)-ruthenium(II) Complex," Analytical Science, Vol. 22, No. 12, 2006, pp. 1547-1551. http://dx.doi.org/10.2116/analsci.22.1547

[19] X. B. Zhang, J. Peng, C. L. He, G. L. Shen and R. Q. Yu, "A Highly Selective Fluorescent Sensor for $\mathrm{Cu}^{2+}$ Based on 2-(2'-Hydroxyphenyl)benzoxazole in a Poly(vinyl chloride) Matrix," Analytica Chimica Acta, Vol. 567, No. 2, 2006, pp. 189-195. http://dx.doi.org/10.1016/j.aca.2006.03.025

[20] H. Y. Luo, X. B. Zhang, J. H. Jiang, C. Y. Li, J. Peng, G. L. Shen and R. Q. Yu, "An Optode Sensor for $\mathrm{Cu}^{2+}$ with High Selectivity Based on Porphyrin Derivative Appended with Bipyridine," Analytical Science, Vol. 23, No. 5, 2007, pp. 551-555. http://dx.doi.org/10.2116/analsci.23.551
[21] Y. Q. Weng, F. Yue, Y. R. Zhong and B. H. Ye, “A Copper(II) Ion-Selective On-Off-Type Fluoroionophore Based on Zinc Porphyrin-Dipyridylamino," Inorganic Chemistry, Vol. 46, No. 19, 2007, pp. 7749-7755. http://dx.doi.org/10.1021/ic061709v

[22] N. Shao, Y. Zhang, S. M. Cheung, R. H. Yang, W. H. Chan, T. Mo, K. A. Li and F. Liu, "Copper Ion-Selective Fluorescent Sensor Based on the Inner Filter Effect Using a Spiropyran Derivative," Analytical Chemistry, Vol. 77, No. 22, pp. 2005, pp. 7294-7303. http://dx.doi.org/10.1021/ac051010r

[23] N. Shao, J. Y. Jin, H. Wang, Y. Zhang, R. H. Yang and W. H. Chan, "Tunable Photochromism of Spirobenzopyran via Selective Metal Ion Coordination: An Efficient Visual and Ratioing Fluorescent Probe for Divalent Copper Ion," Analytical Chemistry, Vol. 80, No. 9, 2008, pp. 3466-3475. http://dx.doi.org/10.1021/ac800072y

[24] X. Qi, E. J. Jun, L. Xu, S. J. Kim, J. S. Hong and Y. J. Yoon and J. Yoon, "New BODIPY Derivatives as OFFON Fluorescent Chemosensor and Fluorescent Chemodosimeter for $\mathrm{Cu}^{2+}$ : Cooperative Selectivity Enhancement toward $\mathrm{Cu}^{2+}$," The Journal of Organic Chemistry, Vol. 71, No. 7, 2006, pp. 2881-2884.

http://dx.doi.org/10.1021/jo052542a

[25] N. Narayanan and G. Patonay, "A New Method for the Synthesis of Heptamethine Cyanine Dyes: Synthesis of New Near-Infrared Fluorescent Labels," The Journal of Organic Chemistry, Vol. 60, No. 8, 1995, pp. 2391-2395. http://dx.doi.org/10.1021/jo00113a018

[26] L. Yuan, W. Y. Lin, K. B. Zheng, L. W. He and W. M. He, "Far-red to Near Infrared Analyte-Responsive Fluorescent Probes Based on Organic Fluorophore Platforms for Fluorescence Imaging," Chemical Society Reviews, Vol. 42, 2013, pp. 622-661. http://dx.doi.org/10.1039/c2cs35313j

[27] P. Li, X. Duan, Z. Z. Chen, Y. Liu, T. Xie, L. B. Fang, X. R. Li, M. Yin and B. Tang, "A Near-Infrared Fluorescent Probe for Detecting Copper(II) with High Selectivity and Sensitivity and Its Biological Imaging Applications," Chemical Communications, Vol. 47, 2011, pp. 7755-7757. http://dx.doi.org/10.1039/c1cc11885d

[28] B. Tang, H. Huang, K. H. Xu, L. H. Tong, G. W. Yang, X. Liu and L. G. An, "Highly Sensitive and Selective NearInfrared Fluorescent Probe for Zinc and Its Application to Macrophage Cells," Chemical Communications, Vol. 34, 2006, pp. 3609-3611. http://dx.doi.org/10.1039/b606809j

[29] W. H. Liu, Y. Wang, J. H. Tang, G. L. Shen and R. Q. Yu, "An Optical Fiber Sensor for Berberine Based on Immobilized 1,4-Bis(Naphth[2,1-d]Oxazole-2-yl)Benzene in a New Copolymer," Talanta, Vol. 46, No. 4, 1998, pp. 679688. http://dx.doi.org/10.1016/S0039-9140(97)00330-5 